\title{
RESTAURANT AND HOTEL MARKET IN POLAND
}

\section{EDYTA GHERIBI}

\begin{tabular}{|c|c|}
\hline & $\begin{array}{l}\text { University of Lodz } \\
\text { e-mail: edyta.gheribi@uni.lodz.pl }\end{array}$ \\
\hline $\begin{array}{l}\text { RECEIVED } \\
\text { ACCEPTED }\end{array}$ & $\begin{array}{l}26 \text { March } 2015 \\
8 \text { August } 2015\end{array}$ \\
\hline $\begin{array}{l}\text { JEL } \\
\text { CLASSIFICATION }\end{array}$ & D47 \\
\hline KEYWORDS & market, restaurant, hotel, tourism, development, management \\
\hline ABSTRACT & $\begin{array}{l}\text { This article presents the development of restaurant and hotel market in Poland. Despite the decreasing total } \\
\text { number of catering establishments, the number of restaurants in } 2013 \text { increased by } 98.8 \% \text { compared to } 2000 \text {. } \\
\text { The data of CSO shows that the highest concentration of restaurants was in Mazowieckie voivodship, where } \\
\text { there were } 1209 \text { in } 2013 \text {, which accounted for } 22.96 \% \text { of all restaurants in Poland. The sector is growing and at- } \\
\text { tracting new investments and good future perspectives are foreseen. Restaurants constitute the most lucrative } \\
\text { segment of the catering market, generating almost } 60 \% \text { of the sector's aggregated values. Analysts forecast } \\
\text { further expansion of restaurant facilities in shopping malls, city centers, high streets and along important com- } \\
\text { munication routes. Also we can observe a sustainable increase in the number of hotels operating in Poland. } \\
\text { At the end of } 2013 \text { there were } 2107 \text { hotels with a total capacity of } 1,058,000 \text { rooms. Their number had increased } \\
\text { in } 2013 \text { compared to } 2000 \text { by } 128.03 \% \text {, until it reached the number of } 2107 \text { hotels in } 2013 \text { compared to } 924 \text { ho- } \\
\text { tels in } 2000 \text {. The distribution of hotel facilities on the map of Poland is not regular. Considering the number of } \\
\text { existing hotels, Małopolskie voivodship is the unquestioned leader ( } 286 \text { hotels in } 2013 \text { ) with the strong supply } \\
\text { being a regional characteristics. The hotel market in Poland as compared to other European countries is not } \\
\text { large. Such a small. not saturated market presents sianificant development opportunities. }\end{array}$ \\
\hline
\end{tabular}

\section{Introduction}

The context in which the modern consumer has operated in the past decades (the development of civilization, globalization, accelerating the pace of life, the invasion of new products and patterns of behavior, change in the economic and socio-demographic in the country, etc) has made changes in the general model of consumption, including service consumption. In today's world market services related to leisure and recreation play an important 
role, as they cater to the changing needs of consumers (Boguszewicz-Kreft, 2003; Dabrowska, 2008; Gheribi, 2013). In Poland during the last 13 years, the conditions of food preparation and consumption have changed significantly (Babicz-Zielińska, Zabrocki, 2006; Kowrygo, Halicka, 2011; Gheribi, 2013). At present, more and more frequently we eat at a time and place that we find convenient i.e.: in a restaurant, canteen etc., or at a place "on our way". The development of the restaurant and hotel industry is closely linked with the evolution of transportation and economic development, which led to the emergence of a new industry - tourism (Knowles, 2003). Thanks to the development of tourism and the increased number of visitors to Poland, as well as domestic tourists, the creation of new options was forced. This in turn encourages tourists to visit places with developed infrastructure and restaurants and hotels, among other things. This applies mainly to large cities, but can apply to smaller cities.

Restaurants and hotels are ones of the most vigorous sectors of the Polish economy. The number of restaurants and hotels increased in every year since starting the analysis in 2000 . Also in more recent years the revenue from restaurants and hotels grew. The aim of this article is to analyse the current situation of the restaurant and hotel market in Poland and its development perspectives. The paper uses secondary sources of information such as statistical data of the Central Statistical Office (CSO), business reports, and industry newsletters and publications. The research period was between the years 2000-2013. A comparative method was applied for the analysis of collected data and materials.

\section{Polish restaurant mapket}

A restaurant is a catering facility available for all consumers, with full waiter service, offering a wide and diverse range of food and drink, offered to consumers by card menus. The facility meets the basic and exclusive needs of the consumer, providing him with both leisure and entertainment as well as specialized food preparation. According to CSO data, in 2013 there were 16,936 restaurants, compared to 8,519 in 2000, 10,927 in 2007 and 14,937 in 2010 (Table 1). The number of catering establishments in 2013 increased by $98.8 \%$ compared to 2000. At present most catering establishments, approximately $98.2 \%$, are privately owned. The catering establishment structure is dominated by bars ( $37.21 \%$ of the total number) and eating facilities such as food stands ( $31.68 \%$ of the total number). The next largest group consists of restaurants $(25.01 \%$ of total number). According to CSO data most restaurants are located in Mazowieckie (22.96\%), Małopolskie (12.68\%) and Śląskie (12.02\%). In most voivodships in 2013 compared to 2010 there is an increased number of restaurants (Table 2). The number of restaurants

Table 1. Number of catering establishments and market share in \% in Poland in years 2000-2013

\begin{tabular}{|c|c|c|c|c|c|c|c|c|c|c|c|c|}
\hline Specification & 2007 & $\%$ & 2010 & $\%$ & 2011 & $\%$ & 2012 & $\%$ & 2013 & $\%$ & $\begin{array}{c}\text { Change } \\
\text { (increase/ } \\
\text { decrease) } \\
2013 / 2000 \\
(\%)\end{array}$ & $\begin{array}{c}\text { Change } \\
\text { (increase/ } \\
\text { decrease) } \\
2013 / 2007 \\
(\%)\end{array}$ \\
\hline Total & 88,995 & 100.0 & 70,483 & 100.0 & 67,356 & 100.0 & 68,787 & 100.0 & 67,693 & 100.0 & -19.74 & -23.93 \\
\hline Restaurants & 10,927 & 12.2 & 14,937 & 21.2 & 15,287 & 22.7 & 16,478 & 23.9 & 16,936 & 25.0 & +98.80 & +54.99 \\
\hline Bars & 38,391 & 43.1 & 27,145 & 38.5 & 25,866 & 38.4 & 25,885 & 37.6 & 25,195 & 37.2 & -30.86 & -34.37 \\
\hline Eating facilities & 33,717 & 37.8 & 23,892 & 33.9 & 21,932 & 32.6 & 21,120 & 32.2 & 21,447 & 31.6 & -33.76 & -63.60 \\
\hline Canteens & 6,576 & 6.9 & 4,509 & 6.4 & 4,271 & 6.3 & 4,304 & 6.3 & 4,115 & 6.1 & -41.30 & -37.42 \\
\hline
\end{tabular}

Source: own calculations based on CSO (GUS) data, Statistical Yearbook of Poland 2000, 2007, 2010, 2011, 2012, 2013. 
increased mostly in Mazowieckie, where the Polish capital city Warszawa is located. According to CSO data, the number of restaurants in Mazowieckie in 2013 increased by $32.42 \%$ compared to 2010 and $76.23 \%$ compared to 2007. The geographic distribution of catering enterprises is uneven in the regions of Poland, as shown in Table 2.

Tahle 2. Number of catering establishments by voivodships in Poland in years $2007-2013^{*}$

\begin{tabular}{|c|c|c|c|c|c|c|c|}
\hline \multirow[b]{2}{*}{ Voivodships } & \multicolumn{7}{|c|}{ Restaurants } \\
\hline & 2007 & 2010 & 2011 & 2012 & 2013 & $\begin{array}{c}\text { Change } \\
\text { (increase or decrease) } \\
2013 / 2000 \\
(\%)\end{array}$ & $\begin{array}{c}\text { Change } \\
\text { (increase or decrease) } \\
2013 / 2007 \\
(\%)\end{array}$ \\
\hline Poland & 3,673 & 4,625 & 4,447 & 4,806 & 5,264 & +91.49 & +43.32 \\
\hline Dolnośląskie & 311 & 414 & 413 & 420 & 450 & +41.51 & +44.69 \\
\hline Kujawsko-pomorskie & 176 & 181 & 167 & 184 & 201 & +53.44 & +14.20 \\
\hline Lubelskie & 93 & 123 & 137 & 146 & 177 & +180.95 & +90.32 \\
\hline Lubuskie & 97 & 107 & 99 & 87 & 91 & 0.00 & -6.18 \\
\hline Łódzkie & 174 & 287 & 250 & 185 & 214 & +118.37 & +22.98 \\
\hline Małopolskie & 371 & 515 & 480 & 612 & 668 & +139.43 & +80.05 \\
\hline Mazowieckie & 686 & 913 & 938 & 1,120 & 1,209 & +226.76 & +76.23 \\
\hline Opolskie & 95 & 94 & 77 & 99 & 100 & +16.28 & +5.26 \\
\hline Podkarpackie & 132 & 183 & 206 & 184 & 208 & +123.66 & +57.57 \\
\hline Podlaskie & 81 & 107 & 107 & 101 & 114 & +70.15 & +40.74 \\
\hline Pomorskie & 179 & 234 & 215 & 230 & 311 & +61.14 & +73.74 \\
\hline Śląskie & 491 & 570 & 548 & 594 & 633 & +68.35 & +28.92 \\
\hline Świętokrzyskie & 68 & 93 & 93 & 113 & 115 & +94.92 & +69.11 \\
\hline Warmińsko-mazurskie & 141 & 162 & 147 & 157 & 173 & +53.10 & +22.69 \\
\hline Wielkopolskie & 406 & 432 & 398 & 403 & 397 & +36.43 & -2.21 \\
\hline Zachodniopomorskie & 172 & 210 & 172 & 171 & 203 & +67.77 & +18.02 \\
\hline
\end{tabular}

Source: own calculations based on CSO (GUS) data, Statistical Yearbook of the Regions Poland 2007, 2010, 2011, $2012,2013$.

A major element that shows the increase of catering market is the systematic growth of revenue. Poland's restaurant market may have reached, according to preliminary estimates, the value of some 23 bln zl, data included in researcher PMR's report "HoReCa Market in Poland 2014" (Frontczak, 2013). Poland's restaurant market is growing on average by 2-3\% annually. According to CSO data, in 2013 the revenue was $25701 \mathrm{mln}$ zl, and this was increased by $27.10 \%$ compared to 2007 .

Tahle 3. Revenues from catering activity (current prices) in mln zl in years 2000-2013 in Poland

\begin{tabular}{|c|c|c|c|c|c|c|c|}
\hline Specification & 2007 & 2010 & 2011 & 2012 & 2013 & $\begin{array}{c}\text { Change } \\
\text { (increase/decrease) } \\
2013 / 2000(\%)\end{array}$ & $\begin{array}{c}\text { Change } \\
\text { (increase/decrease) } \\
2013 / 2007(\%)\end{array}$ \\
\hline Revenues from catering activity & 20,220 & 21,683 & 22,782 & 24,868 & 25,701 & +67.09 & +27.10 \\
\hline From catering production & 12,286 & 15,022 & 15,833 & 17,788 & 18,661 & +141.08 & +51.88 \\
\hline $\begin{array}{l}\text { From sale of trade commodities } \\
\text { including alcoholic beverages, } \\
\text { tobacco }\end{array}$ & 7,369 & 6,043 & 6,319 & 6,499 & 6,452 & -7.40 & -17.99 \\
\hline From other activity & 565 & 617 & 630 & 581 & 588 & -12.70 & +9.20 \\
\hline
\end{tabular}

Source: own calculations based on CSO (GUS) data, Statistical Yearbook of Poland 2000, 2007, 2010, 2011, 2012, 2013. 
The revenue of catering establishments is generated mainly by own-food production, followed by alcohol and tobacco sales. It is important to stress that the revenue generated by own-food production has been rapidly increasing. In 2013 , own-production generated $72.60 \%$ of total catering activity revenue. From sale of trade commodities including alcoholic beverages and tobacco $25.10 \%$ of revenue is generated. Only $2.28 \%$ of the revenue was generated by other economic activities (Table 3).

Changing dietary habits, especially among the younger generation, contributes to support market growth. The report "Poland on a plate 2014" drafted by Makro Cash \& Carry, which surveys Poles' eating habits each year, indicates that among the youngest adult age group (18-24 years of age) the percentage of people eating out at least once a week amounts to $63.9 \%$ (Anon, 2014). "The older a person is, the more uncommon it is for them to eat bigger meals outside (only $7.6 \%$ among persons over 65 years of age). Consumers indicate that this is caused primarily by pecuniary reasons. Poles would more often choose fast food restaurants, which allowed them to continue to draw the benefits of eating out at a lower, more affordable price. PMR experts' forecast for 2014, however, is already optimistic: market growth is expected to reach $3 \%$ this year and the situation will improve by the month (Frontczak, 2014). What is more, forecasts for the coming years are also optimistic.

\section{Polish hotel industry}

A hotel is a categorized facility which meets the requirements of a hotel facility specified in the appropriate regulation of the Council of Ministers. Other facilities are categorized as other accommodation facilities. We can observe a sustainable increase in the number of hotels operating in Poland. At the end of 2013 there were 2,107 hotels with a total capacity of 1,058 thousand rooms. Their number had increased in 2013 compared to 2000 by $128.03 \%$, until it reached the number of 2,107 hotels in 2013 compared to 924 hotels in 2000 (Table 4). According to Eurostat data (2013), Poland has experienced the greatest increase in number of new rooms among eight other CEE countries.

The great majority of these constituted $3^{*}$ facilities ( $48 \%$ of the market share considering the number of hotels, $42 \%$ of the market share considering the number of hotel rooms). In second place considering the number of hotels are $2^{*}$ facilities ( $29 \%$ market share), however if one considers the number of hotel rooms, $4^{*}$ hotels prevail $(25 \%$ market share). Interesting relations are noticeable in the $1^{*}$ and the $5^{*}$ hotel segment. In Poland, $5^{*}$ hotels constitute the least numerous group (50 hotels, market share at a level of $2 \%$ ), however the number of rooms they do offer is comparable to the number supplied by $1^{*}$ hotels, of which there are almost four times as many (195 hotels). An analysis of the hotel occupancy rates per category shows a relation between the hotel category and its average occupancy rate. A higher hotel category, means, on average, higher occupancy rates (hotels $5^{*}-66 \%, 4^{*}-50 \%$, $3^{*}-41 \%, 2^{*}-39 \%, 1^{*}-34 \%$ ) (Figure 1). The only exception to this rule are $1^{*}$ hotels, which record occupancy rates at the same level as $3^{*}$ facilities.

Since last year there has been a significant rise in the role of tourism in building the national GDP (Figure 2). The Polish hotel industry has only just achieved the level of relative market balance which satisfies both the hotel owners and the guests. The state has been achieved as a result of large investment projects implemented in recent years in this sector. This shows the importance of this area of investment in Poland and how strongly it continues to develop. 


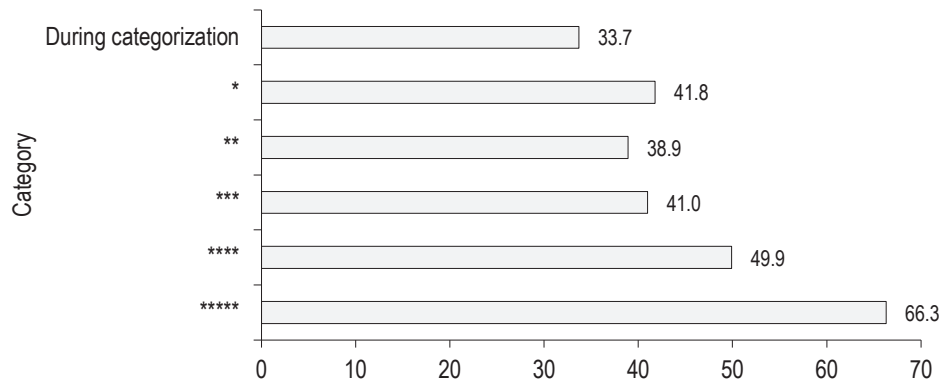

Figure 1. Occupancy rate of hotels rooms in 2013 (I-XII) in \%

Source: own calculations based on CSO (GUS) data, Tourism in 2013.

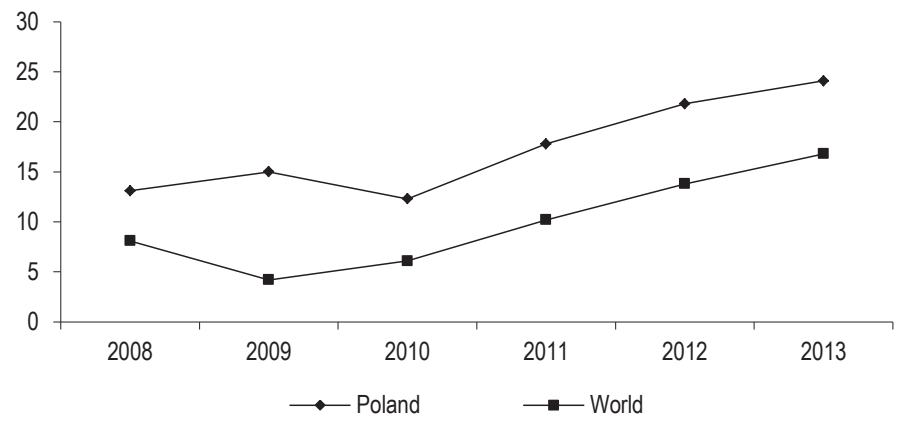

Figure 2. The cumulative growth in the share of tourism in GDP in Poland and the World in \% in 2008-2013

Source: own calculations based on Eurostat data 2008, 2009, 2010, 2011, 2012, 2013.

Table 4. Selected tourist accommodation establishments in Poland in years 2000-2013

\begin{tabular}{|c|c|c|c|c|c|c|c|c|c|c|c|c|}
\hline \multirow[b]{2}{*}{ Specification } & \multicolumn{6}{|c|}{ Number of establishments in collective accommodation } & \multicolumn{6}{|c|}{$\begin{array}{l}\text { Number of beds in collective accommodation facilities } \\
\text { in thousands }\end{array}$} \\
\hline & 2007 & 2010 & 2011 & 2013 & $\begin{array}{c}\text { change } \\
\text { (increase } \\
\text { or decrease) } \\
2013 / 2000 \\
(\%)\end{array}$ & $\begin{array}{c}\text { change } \\
\text { (increase } \\
\text { or decrease) } \\
2013 / 2007 \\
(\%)\end{array}$ & 2007 & 2010 & 2011 & 2013 & $\begin{array}{c}\text { change } \\
\text { (increase } \\
\text { or decrease) } \\
2013 / 2000 \\
(\%)\end{array}$ & $\begin{array}{c}\text { change } \\
\text { (increase } \\
\text { or decrease) } \\
2013 / 2007 \\
(\%)\end{array}$ \\
\hline Total & 6,718 & 7,206 & 7,039 & 9,775 & +25.03 & +45.50 & 582.10 & 610.10 & 606.20 & 679.40 & +4.25 & +16.71 \\
\hline Hotels & 1,370 & 1,796 & 1,883 & 2,107 & +128.03 & +53.79 & 141.12 & 176.00 & 186.96 & 208.60 & +119.34 & +47.83 \\
\hline Hotels $5^{*}$ & 19 & 43 & 45 & 47 & +683.33 & +147.36 & 7.31 & 10.78 & 10.79 & 11.31 & +489.06 & +54.71 \\
\hline Hotels $4^{*}$ & 72 & 162 & 180 & 224 & +460.00 & +211.11 & 18.41 & 33.69 & 38.60 & 53.49 & +425.44 & +190.54 \\
\hline Hotels $3^{*}$ & 503 & 779 & 845 & 910 & +173.27 & +80.91 & 60.04 & 73.68 & 77.98 & 85.47 & +98.72 & +42.35 \\
\hline Hotels 2* & 434 & 510 & 518 & 551 & +93.33 & +26.95 & 36.41 & 38.35 & 39.06 & 41.01 & +76.31 & +12.63 \\
\hline Hotels $1^{*}$ & 152 & 177 & 174 & 177 & -31.93 & +16.44 & 11.27 & 11.89 & 11.96 & 11.62 & -30.42 & +3.10 \\
\hline $\begin{array}{l}\text { During catego- } \\
\text { rization }\end{array}$ & 115 & 125 & 121 & 99 & - & -13.92 & 7.65 & 7.63 & 8.55 & 5.68 & - & -25.76 \\
\hline
\end{tabular}

Source: own calculations based on CSO (GUS) data, Tourism in 2000, 2007, 2010, 2011, 2013. 
The distribution of hotel facilities on the map of Poland is not regular. Considering the number of existing hotels, Małopolskie voivodship is the unquestioned leader (286 hotels) with the strong supply being a regional characteristic. The undisputed leader among provincial capital cities when it comes to the number of hotels has been, for a number of years, and in 2013, Kraków. Kraków, a voivodship capital, is a regional business and tourist centre as well as the most popular Polish tourist destination for foreigners. The voivodship is visited by a dozen or so million people every year. There are 128 hotels in Kraków, including small boutique type facilities (Table 5). But, in terms of hotel rooms, Kraków $(8,540)$ is beaten by Warszawa (11,354), which has as much as $46.87 \%$ less hotels, but has $32.95 \%$ more rooms than Kraków, whereas the biggest demand for rooms is generated by the Mazowieckie voivodship, predominantly due to the facilities located in Warszawa. In Warszawa typical accommodation facilities are geared for the requirements of a business guest, who expects a certain quality of service. Therefore, Warsaw's hotels are, to a large extent, quality chain facilities of the highest category providing standardized services adapted for the needs of business guests. Data gathered by CSO, shows that Warsaw (66.5) and Cracow (61.9) were in the leading position in terms of occupancy rate of rooms in 2013. Average hotel occupancy rate in Poland, according to the CSO data in 2013 was $43.6 \%$. The next provincial capitals with the largest choice of accommodation are Poznań and Wrocław (Table 5). The smallest numbers of hotels are to be found in regions with the smallest business and tourist potential, such as Opolskie or Podlaskie voivodships.

Table 5. Number of formally categorised hotels in Poland in $2013^{*}$ by biggest cities

\begin{tabular}{lccccccc}
\hline \multirow{2}{*}{ Categories } & \multicolumn{7}{c}{ Number of hotels } \\
\cline { 2 - 8 } & Warszawa & Kraków & Poznań & Wrocław & Gdańsk & Łódź & Szczecin \\
\hline$* * * *$ & 9 & 10 & 2 & 5 & 4 & 0 & 0 \\
$* * * *$ & 10 & 24 & 8 & 10 & 8 & 5 & 4 \\
$* * *$ & 23 & 68 & 27 & 21 & 16 & 13 & 6 \\
$* *$ & 17 & 19 & 11 & 4 & 8 & 10 & 4 \\
& 8 & 5 & 1 & 3 & 0 & 3 & 5 \\
\hline Total & 68 & 128 & 50 & 43 & 37 & 31 & 19 \\
\hline
\end{tabular}

'Facilities as of 31.VII.2013.

Source: own calculations based on CSO (GUS) data, Tourism in 2013.

\section{Conclusions}

In conclusion within the last decade, the number of hotels and restaurants have significantly increased and it shows how important this area of investment is in Poland and how strongly it continues to develop. An analysis of data presented on the diagrams of the Polish restaurant and hotel market will show an upward trend. We should also consider the increase of the financial resources of Poles, who are frequent guests in hotels and restaurants in Poland, as well as the sustainable economic development of the country, improvement of the infrastructure and increase in foreign tourists, etc. All these circumstances will certainly contribute to the situation that in the forthcoming years the number of tourists coming to Poland and the number of people using hotels and restaurants services will continuously increase. Poland is considered by many official organizations as one of the most attractive tourist destinations in the world. 


\section{References}

Annon (2014). Polak w restauracji. Raport 2014. Rynek Gastronomiczny w Polsce. Warszawa.

Babicz-Zielińska, E. \& Zabrocki, R. (2006). Zachowania konsumentów na rynku wybranych form usług żywieniowych. Handel Wewnętrzny, 6.

Boguszewski-Kreft, M. (2003). Usługi jako wiodący sektor współczesnej gospodarki. Handel Wewnętrzny, 4-5.

Dąbrowska, A. (2008). Rozwój rynku usług w Polsce: uwarunkowania i perspektywy. Warszawa: SGH.

Frontczak, J. (2014). Gastronomia na prostej - gdzie jesteśmy, trendy, nastroje. Warszawa: Food Business Forum.

Gheribi, E. (2013). Konsument i przedsiębiorstwo na rynku usług gastronomicznych. Jastrzębie Zdrój: Black Unicorn.

Knowles, T. (2001). Zarządzanie hotelarstwem i gastronomią. Warszawa: PWE.

Kowrygo, B. \& Halicka, E. (2011). Development of food services In Poland. Culinary Arts and Sciences. International Centre for Tourism and Hospitality Research Bournemounth University.

Cite this article aS: Gheribi, E. (2015). Restaurant and hotel market in Poland. Szczecin University Scientific Journal, No. 883. Service Management, 16 (2): 57-63 
